\title{
Selective Growth of Rat Schwann Cells in Neuron- and Serum-Free Primary Culture
}

\author{
Leila K. Needham, ${ }^{a}$ Gihan I. Tennekoon, and Guy M. McKhann \\ Department of Neurology, The Johns Hopkins University School of Medicine, Baltimore, Maryland 21205
}

\begin{abstract}
A serum-free medium, designated $\mathbf{S 4}$ [consisting of Eagle's Minimum Essential Medium supplemented with the following components (mg/liter): endothelial mitogen, 100; vitamin C, 1; insulin, 5; cholera toxin, 0.01; putrescine, 8; sodium selenite, $0.0043 ; \mathrm{MgCl}_{2} \cdot 6 \mathrm{H}_{2} \mathrm{O}, 40$; and albumin, fatty acids, amino acids, vitamins, and trace elements], has been established to select for the growth of Schwann cells from primary cultures of dissociated neonatal rat sciatic nerve in the absence of neurons and without exposure of the cells to serum or antimitotic agents. By immunological criteria, confluent primary cultures, grown on a substrate of extracellular matrix derived from cultured bovine aorta endothelial cells, consist of approximately $90 \%$ Schwann cells after maintenance in this serum-free medium. Secondary cultures of at least $99 \%$ purity may be established after treatment of primary cultures maintained in $\mathbf{S 4}$ with antiserum against a fibroblast surface antigen, Thy 1.1 , in conjunction with complement. Such secondary Schwann cells continue to proliferate in S4, with no decrease in purity, through at least 4 passages.
\end{abstract}

The Schwann cell is responsible for the elaboration and maintenance of the myelin sheath that surrounds large-diameter axons in the PNS. Schwann cell differentiation into a myelin-producing cell depends upon specific axonal signals, on the formation of a basal lamina by the Schwann cell, and on the presence of soluble factors in the extracellular environment (Aguayo et al., 1976; Moya et al., 1980; Bunge and Bunge, 1983). The role of each of these determinants in the induction of Schwann cell differentiation may be best analyzed in a defined in vitro system in which the effects of hormones, vitamins, and other soluble factors may be examined on pure cultures of Schwann cells in isolation or in combination with basal lamina components and/ or neurons.

The traditional culture of cells in serum-supplemented medium complicates the analysis of the hormonal control of differentiation because of the presence of undefined amounts of hormones and of factors that can attenuate or potentiate hormonal actions. Furthermore, serum selects for the active pro-

Received July 8, 1985; revised June 3, 1986; accepted June 30, 1986.

This work was supported by grants from the National Institutes of Health (5P01NS-15721, 1 P01-22845, and NS21 700), the Multiple Sclerosis Society (RG. 1740), and the Kroc Foundation. We wish to thank Dr. Bert Glaser for the bovine aorta endothelial cells and Dr. Pamela Talalay for helpful discussion.

Correspondence should be addressed to Dr. Gihan I. Tennekoon, Department of Neurology, The Johns Hopkins University School of Medicine, Room 6-119, Meyer Building, 600 N. Wolfe St., Baltimore, MD 21205.

a Present address: Department of Neuroscience, The Johns Hopkins University School of Medicine, $725 \mathrm{~N}$. Wolfe St., Baltimore, MD 21205.

Copyright (C) 1987 Society for Neuroscience 0270-6474/87/010001-09\$02.00/0 liferation of fibroblasts, resulting in a reliance upon antimitotic agents to yield cultures devoid of fibroblasts.

An expanding population of pure Schwann cells may be obtained from dissociated cultures of rat sciatic nerve maintained in serum-supplemented medium by a method established by Brockes et al. (1979), which entails the use of antimitotic agents followed by specific immune-mediated lysis of fibroblasts. We have eliminated serum from the culture medium in order to reduce fibroblast proliferation without the use of antimitotic agents and to provide a more defined environment for studies of Schwann cell function in vitro. Furthermore, since neural cells are never exposed to serum in vivo, except as a consequence of pathology, the elimination of serum may provide a medium that is closer to the normal in situ environment.

Committed Schwann cells in vivo are characterized by the presence of a basal lamina, even in the absence of axons. Isolated Schwann cells do not, however, have a demonstrable basal lamina in vitro unless they are cultured in contact with neurons (Bunge et al., 1982). Since exogenously supplied basal lamina components have been shown to affect cell differentiation in vitro (Reid and Jefferson, 1984), we have supplied the Schwann cells with a substrate of basal lamina-like extracellular matrix (ECM) elaborated by cultured bovine aorta endothelial cells (Gospodarowicz et al., 1981) and have assessed their state of differentiation using antisera directed against antigens characteristic of myelinating and nonmyelinating Schwann cells in vivo. A preliminary report of this work has been presented (Needham et al., 1985).

\section{Materials and Methods \\ Tissue dissociation}

Tissue was dissociated by a modification of the method of Brockes et al. (1979). Sciatic nerves from 3-d-old Sprague-Dawley rats were excised and pooled in Dulbecco's calcium- and magnesium-free PBS supplemented with $2.5 \mathrm{mg} / \mathrm{ml}$ glucose, $6 \mathrm{mg} / \mathrm{ml}$ BSA (Pentex), $0.76 \mathrm{mg} / \mathrm{ml}$ $\mathrm{MgSO}_{4} \cdot 7 \mathrm{H}_{2} \mathrm{O}$, and $50 \mu \mathrm{g} / \mathrm{ml}$ gentamycin (PBSA). The nerves were washed and digested at $37^{\circ} \mathrm{C}$ for $20 \mathrm{~min}$ in $0.1 \%$ collagenase (Worthington CLS III) in PBSA followed by further digestion $(30 \mathrm{~min})$ in $0.1 \%$ trypsin (Worthington TRL3) and $0.005 \%$ deoxyribonuclease I (DNase; Worthington D) in PBSA. Then, $0.005 \%$ soybean trypsin inhibitor (Worthington SI) and $0.004 \%$ DNase in PBSA were added, and the nerves were dissociated by 6 cycles of trituration through 21 and 23 gauge needles. The resulting cell suspension was passed through a $110 \mu \mathrm{m}$ pore nylon mesh, and centrifuged before resuspension and plating. The yield was about $1.6-2.0 \times 10^{7}$ cells per 20 rats. More than $95 \%$ of these cells excluded trypan blue, and approximately $10 \%$ were fibroblasts by indirect immunofluorescence criteria.

\section{Cell growth and dose response}

Two procedures were used to establish primary cultures for the subsequent analysis of growth in serum-free medium.

Procedure 1: Pretreatment with antimitotic agents. Dissociated sciatic 
nerve cells were resuspended in Dulbecco's Modified Eagle's Medium (DMEM) containing 10\% fetal bovine serum (FBS) and $1 \times 10^{-5} \mathrm{M}$ cytosine arabinoside (Ara C), and $3 \times 10^{5}$ cells were plated in $1 \mathrm{ml}$ of medium $/ 35 \mathrm{~mm}$ Contur style dish (Lux) coated with ECM unless indicated otherwise. After $3 \mathrm{~d}$, the cells were washed twice in basal medium and replenished with $1 \mathrm{ml}$ of supplemented serum-free medium.

Procedure 2: Establishment in serum-free medium. Dissociated sciatic nerve cells were given an additional wash with trypsin inhibitorDNase solution and resuspended in supplemented serum-free medium, and $1 \times 10^{5}$ cells were plated in $1 \mathrm{ml}$ of medium $/ 35 \mathrm{~mm}$ dish coated with ECM unless indicated otherwise.

Serum-free medium was changed every $2 \mathrm{~d}$. All cells were cultured in a $10 \% \mathrm{CO}_{2} / 90 \%$ air atmosphere at $36.5^{\circ} \mathrm{C}$ in a humidified incubator. At the appropriate time, cultures were processed for immunofluorescence analysis or were trypsinized for cell number determination. Treatment of the cultures with $1 \mathrm{ml}$ of $0.1 \%$ trypsin- $0.04 \%$ EDTA (Gibco) in $\mathrm{Ca}^{2+}$ and $\mathrm{Mg}^{2+}$-free PBS at $37^{\circ} \mathrm{C}$ for $5 \mathrm{~min}$ followed by gentle trituration resulted in complete dissociation of the cells, regardless of substrate. This suspension was diluted to $10 \mathrm{ml}$ with isotonic saline and counted on a model ZBI Coulter counter. Cell densities are reported as cell number $/ 35 \mathrm{~mm}$ dish and represent the mean of triplicate plates.

\section{Preparation of $E C M$}

Bovine aorta endothelial cells (obtained from Dr. Bert Glaser, The Johns Hopkins University) were maintained in serial culture in DMEM containing $10 \%$ FBS. For the preparation of ECM, the cells were plated at a 1:4 split ratio in DMEM containing 10\% NU-SERUM (Collaborative Research 5000) and maintained until confluent ( $\sim 5 \mathrm{~d})$. ECM was prepared by a method derived from the procedures of Kramer et al. (1980) and Vlodavsky et al. (1982). The cell monolayers were incubated sequentially for $10 \mathrm{~min}$ at $5 \mathrm{~mm}$ Tris- $\mathrm{HCl}, \mathrm{pH} 7.5,5 \mathrm{~min}$ in $0.2 \%$ Nonidet $\mathrm{P}-40(\mathrm{vol} / \mathrm{vol})$ in $5 \mathrm{~mm}$ Tris- $\mathrm{HCl}, \mathrm{pH} 7.5$, and $2-3 \mathrm{~min}$ in $0.025 \mathrm{M}$ $\mathrm{NH}_{4} \mathrm{OH}$ in $5 \mathrm{mM}$ Tris- $\mathrm{HCl}, \mathrm{pH} 7.5$. The ECM was then washed twice with $30 \mathrm{mM} \mathrm{NaCl}, 0.01 \% \mathrm{CaCl}_{2}, 0.01 \% \mathrm{MgCl}_{2} \cdot 6 \mathrm{H}_{2} \mathrm{O}$ (saline D) and fixed by a $30 \mathrm{~min}$ incubation with $0.5 \%$ carbodiimide [1-cyclohexyl-3(2-morpholinoethyl) carbodiimide metho-p-toluenesulfonate: Aldrich C10, 640-2] in saline D. The fixed ECM was then washed twice more with Eagle's Minimum Essential Medium (MEM) with $75 \mathrm{mg} /$ liter $\mathrm{NaHCO}_{3}$ and subsequently stored at $4^{\circ} \mathrm{C}$ in MEM with $75 \mathrm{mg} /$ liter $\mathrm{NaHCO}_{3}$.

\section{Serum-free medium}

The composition of the serum-free media and the sources of the components are listed in Table 1. Class I water (Milli Q, Millipore) was used for medium preparation. When MEM, which is formulated with a bicarbonate concentration designed for proper $\mathrm{pH}$ maintenance in a $5 \% \mathrm{CO}_{2}$ atmosphere, was used as the basal medium, the bicarbonate concentration was augmented in order to maintain the proper $\mathrm{pH}$ in a $10 \% \mathrm{CO}_{2}$ atmosphere. At $10 \% \mathrm{CO}_{2}$, the $\mathrm{pH}$ of the serum-containing and serum-free media was $7.35 \pm 0.05$. Supplemented MEM (S-MEM) was made by adding glucose (to a final concentration of $4500 \mathrm{mg} / \mathrm{liter}$ ) and bicarbonate (to a final concentration of $3700 \mathrm{mg} /$ liter) to MEM prepared from a $10 \times$ final concentration stock (M. A. Bioproducts). The remaining supplements, except vitamin $C$, were prepared as concentrated stocks that were stored frozen or at $4^{\circ} \mathrm{C}$. Appropriate volumes of these stocks were added to the basal medium. Owing to its short halflife $(\sim 10 \mathrm{hr})$ in tissue culture medium (Peterkofsky, 1972), vitamin C was added daily directly to the dishes of cells.

\section{Immunofluorescence}

Ran-1 antiserum produced, absorbed, and characterized as described (Brockes et al., 1977) was obtaincd from Dr. M. Raff(Univcrsity Collcge of London) and was used at a dilution of 1:100. Monoclonal antibody to Thy 1.1 [New England Nuclear (NEN)] was used at a dilution of $1: 100$. Monoclonal anti-217c was obtained in the form of hybridoma supernatant from Dr. K. L. Fields (Albert Einstein School of Medicine) and was used at a dilution of 1:50. The antibody was produced by Peng et al. (1982). Monoclonal anti-A5E3 and Ran-2 were obtained from Dr. R. Mirsky in the form of hybridoma supernatant and were used at dilutions of $1: 5$ and 1:1, respectively. Anti-A5E3 was characterized by Mirsky et al. (1984), and anti-RAN-2 was characterized by Bartlett et al. (1981). Monoclonal anti-galactocerebroside was obtained in the form of ascites fluid from Dr. B. Ranscht (Kings College, London) and was used at a dilution of 1:50. The antibody was characterized by Ranscht et al. (1982). Monoclonal anti-S-100 was obtained in the form of hybridoma supernatant from Dr. Y. Gillespie (University of North Carolina, Chapel Hill) and was used at a dilution of 1:2. Fluorescein-conjugated anti-immunoglobulins were obtained from Cappel and used at dilutions of $1: 20$ or 1:40.

Cells were grown on ECM-coated $35 \mathrm{~mm}$ dishes and were processed with or without fixation. Cells to be stained with antisera directed against Ran-1, Thy $1.1,217 \mathrm{c}$, and galactocerebroside were fixed in $1 \%$ formaldehyde in PBS for 20 min at room temperature; cells to be stained with antisera directed against S-100 were treated in 3.5\% formaldehyde in PBS for $20 \mathrm{~min}$ at room temperature; cells stained with antisera directed against Ran- 2 and A5E3 were treated with $1 \%$ paraformaldehyde in PBS at room temperature for $20 \mathrm{~min}$ followed by treatment with $5 \%$ acetic acid in ethanol for $10 \mathrm{~min}$ at $20^{\circ} \mathrm{C}$. Small circular areas were delineated on the surface of the dish with Dow Corning highvacuum grease, and the cells in these areas were stained in a 2-step indirect immunofluorescence procedure essentially as described by Raff et al. (1979).

\section{Serial subculture}

Dissociated rat sciatic nerve cells were seeded at $1 \times 10^{6}$ cells per T75 flasks (Corning) coated with ECM in $10 \mathrm{ml}$ of S4. Upon attainment of confluence $(\sim 7-9$ d) the cells were harvested with $0.1 \%$ trypsin $0.02 \%$ EDTA in $\mathrm{Ca}^{2+}$ - and $\mathrm{Mg}^{2+}$-free PBS and washed with $0.005 \%$ trypsin inhibitor in S4, and the fibroblasts were lysed essentially as described by Brockes et al. (1979). The cells were treated in suspension with a 1:100 dilution of monoclonal anti-Thy 1.1 (NEN:NEI-002) in MEM plus $1 \%$ BSA for $30 \mathrm{~min}$ at $4^{\circ} \mathrm{C}$, washed, and incubated with a $1: 16$ dilution of freshly reconstituted rabbit complement (Cappel) in S4 for $5 \mathrm{~min}$ at $4^{\circ} \mathrm{C}$ followed by $30 \mathrm{~min}$ at $37^{\circ} \mathrm{C}$. The cells were washed resuspended in S4, and plated at 5-7 $\times 10^{5}$ cells per ECM-coated T75 flask. Cells did not require treatment with antibody and complement upon subsequent passage.

\section{Results}

The goal of these studies was to develop a serum-free medium that supports optimal primary Schwann cell proliferation while suppressing fibroblast proliferation.

In the course of preliminary studies, we investigated the ability of various basal medium formulations to support the proliferation of purified secondary Schwann cells obtained by the method of Brockes (Brockes et al., 1979). Optimal prolifcration of purified Schwann cells was enhanced in DMEM as compared to that in a 1:1 mixture of DMEM and Ham's F12 Nutrient Medium (F12) or in F12 alone. This was true whether the cells were grown in serum-containing medium supplemented with cholera toxin or in serum-free medium augmented with N2 supplements (Bottenstein and Sato, 1979) and cholera toxin.

\section{Primary Schwann cell proliferation in serum-free medium}

The effects of supplements on the proliferation of Schwann cells in serum-free DMEM were assessed in primary cultures. Dissociated sciatic nerve cells were plated on ECM and pretreated with antimitotic agents in the presence of $10 \%$ FBS (Procedure 1 , Materials and Methods) to reduce the fibroblast contamination to less than $2 \%$. After treatment with antimitotic agents, the medium was changed to various formulations of serum-free mixtures, and fibroblast contamination as assessed by indirect immunofluorescence with the fibroblast marker, anti-Thy 1.1, did not increase above $10 \%$.

Modifications of several serum-free medium formulations developed for rat neural cultures were examined for their ability to support primary Schwann cell proliferation. These formulations included N2 medium developed for neuroblastoma cells 


\begin{tabular}{|c|c|c|c|}
\hline Medium & \multicolumn{3}{|l|}{ Components } \\
\hline S-MEM & \multirow{2}{*}{\multicolumn{3}{|c|}{$\begin{array}{l}\text { MEM supplemented to } 4500 \mathrm{mg} / \text { liter glucose and } 3700 \mathrm{mg} / \text { liter } \mathrm{NaHCO}_{3} \text { (basal medium). } \\
\text { DMEM supplemented with } 3574 \mathrm{mg} / \text { liter HEPES, } 5 \mathrm{mg} / \mathrm{liter} \text { insulin, } 1 \mathrm{mg} / \text { liter cholera toxin, } \\
100 \mathrm{mg} / \text { liter transferrin, } 0.0063 \mathrm{mg} / \text { liter progesterone, } 16 \mathrm{mg} / \text { liter putrescine, } 0.0052 \mathrm{mg} / \\
\text { liter } \mathrm{Na}_{2} \mathrm{SeO}_{3}, 0.01 \mathrm{mg} / \text { liter biotin, and } 25 \mathrm{mg} / \text { liter gentamycin. }\end{array}$}} \\
\hline S1 & & & \\
\hline S2 & \multicolumn{3}{|c|}{$\begin{array}{l}\text { S1 plus the components that comprise the albumin/fatty acid, amino acid, vitamin, magnesium, } \\
\text { and trace element supplements listed below, and } 1465 \mathrm{mg} / \text { liter } \mathrm{KCl} \text {. }\end{array}$} \\
\hline S3 & \multicolumn{3}{|c|}{$\begin{array}{l}\text { Iscove's Modified Dulbecco's Medium supplemented with } 20 \mathrm{mg} / \text { liter endothelial mitogen, } 10 \\
\mathrm{mg} / \text { liter vitamin } \mathrm{C} \text {, and } \mathrm{S} 2 \text { supplements except that progesterone was deleted and basal } \\
\text { medium levels of } \mathrm{HEPES}, \mathrm{Na}_{2} \mathrm{SeO}_{3} \text {, nonessential amino acids, and } \mathrm{KCl} \text { were not augmented. }\end{array}$} \\
\hline \multicolumn{2}{|c|}{$\begin{array}{l}\text { S4a } \\
\text { Components }\end{array}$} & Source & $\begin{array}{l}\text { Concentration } \\
\text { (mg/liter) }\end{array}$ \\
\hline \multicolumn{2}{|l|}{ Glucose } & Sigma G-5000 & $4500^{b}$ \\
\hline \multicolumn{2}{|l|}{$\mathrm{NaHCO}_{3}$} & Sigma S-8875 & $3700^{b}$ \\
\hline \multicolumn{2}{|l|}{ HEPES } & Gibco $3-80-5630$ & 3574 \\
\hline \multicolumn{2}{|l|}{ Insulin } & Sigma I-5500 & 5 \\
\hline \multicolumn{2}{|c|}{ Cholera toxin } & Sigma C-3012 & 0.01 \\
\hline \multicolumn{2}{|c|}{ Endothelial mitogen } & ICN Biochem. 160038 & 100 \\
\hline \multicolumn{2}{|c|}{ Vitamin $\mathrm{C}$} & Sigma A-4034 & $1^{c}$ \\
\hline \multicolumn{2}{|c|}{ Putrescine } & Sigma P-7505 & 8 \\
\hline \multicolumn{2}{|c|}{$\mathrm{Na}_{2} \mathrm{SeO}_{3}$} & Sigma S-1382 & 0.0043 \\
\hline \multicolumn{2}{|c|}{ Gentamycin } & TriBio Labs 8450 & 25 \\
\hline \multicolumn{4}{|c|}{ Albumin/fatty acid supplement } \\
\hline \multicolumn{2}{|c|}{ BSA, fatty acid-free } & Sigma A-7511 & 792 \\
\hline \multicolumn{2}{|c|}{ Linoleic acid ${ }^{d}$} & Sigma L-1012 & 1.51 \\
\hline \multicolumn{2}{|c|}{ Linolenic acid ${ }^{d}$} & Sigma L-2376 & 1.00 \\
\hline \multicolumn{4}{|c|}{ Amino acid supplement } \\
\hline \multicolumn{2}{|c|}{ L-Alanine } & Sigma A-3534 & 3.6 \\
\hline \multicolumn{2}{|c|}{ L-Asparagine } & Sigma A-4519 & 4.0 \\
\hline \multicolumn{2}{|c|}{ L-Aspartic acid } & Sigma A-4534 & 4.0 \\
\hline \multicolumn{2}{|c|}{ L-Glutamic acid } & Sigma G-5513 & 4.3 \\
\hline \multicolumn{2}{|c|}{ L-Proline } & Sigma P-4655 & 8.0 \\
\hline \multicolumn{4}{|c|}{ Vitamin supplement } \\
\hline \multicolumn{2}{|l|}{ Biotin } & Sigma B-4501 & 0.024 \\
\hline \multicolumn{2}{|c|}{ D,L-Lipoic acid } & Sigma T-1395 & 0.12 \\
\hline \multicolumn{2}{|c|}{ Vitamin $\mathbf{B}_{12}$} & Sigma V-6629 & 1.35 \\
\hline Magnesi & um supplement $\left(\mathrm{MgCl}_{2} \cdot 6 \mathrm{H}_{2} \mathrm{O}\right)$ & Sigma M-2393 & 40 \\
\hline Trace ele & ment supplement & & \\
\hline $\mathrm{CrCl}_{3}$. & $6 \mathrm{H}_{2} \mathrm{O}$ & Sigma C-1896 & 0.00027 \\
\hline $\mathrm{CuSO}_{4}$ & $\cdot 5 \mathrm{H}_{2} \mathrm{O}$ & Sigma C-8027 & 0.00025 \\
\hline $\mathrm{MnSO}$ & & Sigma M-7634 & 0.00015 \\
\hline $\mathrm{MoO}_{3}$ & & Sigma M-0753 & 0.00014 \\
\hline $\mathrm{ZnSO}_{4}$ & $\cdot 7 \mathrm{H}_{2} \mathrm{O}$ & Sigma Z-0251 & 0.00029 \\
\hline
\end{tabular}

a $\mathrm{S} 4$ consists of MEM supplemented with listed components.

${ }^{b}$ Reflects the final concentration after augmentation of a component present in MEM.

' Added daily.

${ }^{d}$ Bound to fatty acid-free BSA.

(Bottenstein and Sato, 1979) and the serum-free medium developed for primary CNS neurons by Ahmed et al. (1983). The first serum-free modification, S1 (Table 1), tested for support of primary Schwann cell proliferation consisted of DMEM supplemented with the N2 cocktail plus biotin, which enhances schwannoma cell proliferation in serum-free medium (MichlerStuke and Bottenstein, 1982), and cholera toxin, a specific Schwann cell mitogen (Raff et al., 1978a). S1 supported initial
Schwann cell proliferation; however, after $5 \mathrm{~d}$, Schwann cell death occurred. Further supplementation of S1, essentially according to Ahmed's formulation (S2, Table 1) except for the deletion of additional $\mathrm{KCl}$, resulted in increased support of primary cultures maintained for $10 \mathrm{~d}$ in serum-free medium (Fig. 1).

Additional experiments to evaluate the effects of individual components on cell growth resulted in the identification of en- 


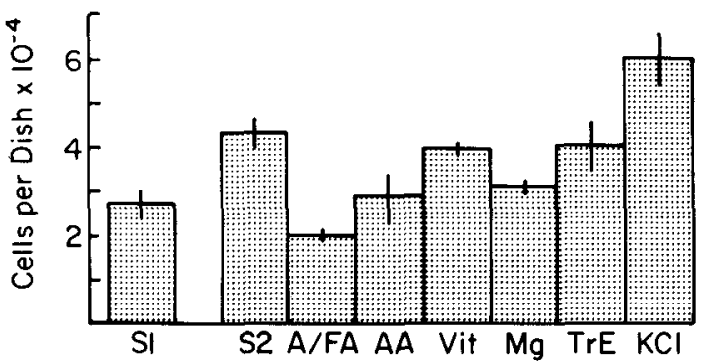

Figure 1. Effect of supplement deletions on primary cell density in serum-free medium. Primary Schwann cell cultures were plated on 35 $\mathrm{mm}$ dishes coated with extracellular matrix and then pretreated with an antimitotic agent in the presence of $10 \%$ FBS (Procedure 1, Materials and Methods). Cell number was determined $10 \mathrm{~d}$ after the medium was changed to the serum-free medium formulations. S1 and S2 represent complete $\mathrm{S} 1$ and $\mathrm{S} 2$ serum-free medium, respectively. The remaining abbreviations represent $\mathrm{S} 2$ serum-free medium lacking the specified supplement: $A / F A$, albumin/fatty acid supplement; $A A$, amino acid supplement; Vit, vitamin supplement; $M g$, magnesium supplement; $\operatorname{Tr} E$, trace element supplement; $K C l, 1465 \mathrm{mg} / \mathrm{liter} \mathrm{KCl}$. (S1 and S2 serumfree medium and supplement formulations are given in Table 1.)

dothelial mitogen, a commercially available pituitary extract [ICN Biochemicals: prepared by the sequential extraction of bovine pituitary with $0.1 \mathrm{M} \mathrm{NaCl}$ and $0.5 \%$ streptomycin sulfate at pH 7.0 (Maciag et al., 1979)], and vitamin $\mathrm{C}$ as components that resulted in significant and consistent increases in cell number. Progesterone $(0.0063 \mathrm{mg} /$ liter $)$, triiodothyronine $(0.0004$ $\mathrm{mg} /$ liter), thyroxin (0.0003 $\mathrm{mg} /$ liter), dexamethasone (100 nM), ethanolamine (1.22 mg/liter), fetuin (125-500 mg/liter), and retinol acetate $(50 \mathrm{mg} /$ liter) exerted no significant growth-promoting effects in serum-free medium. For further analysis of those compounds that demonstrated a positive effect, the relationship between the concentration of a given supplement and

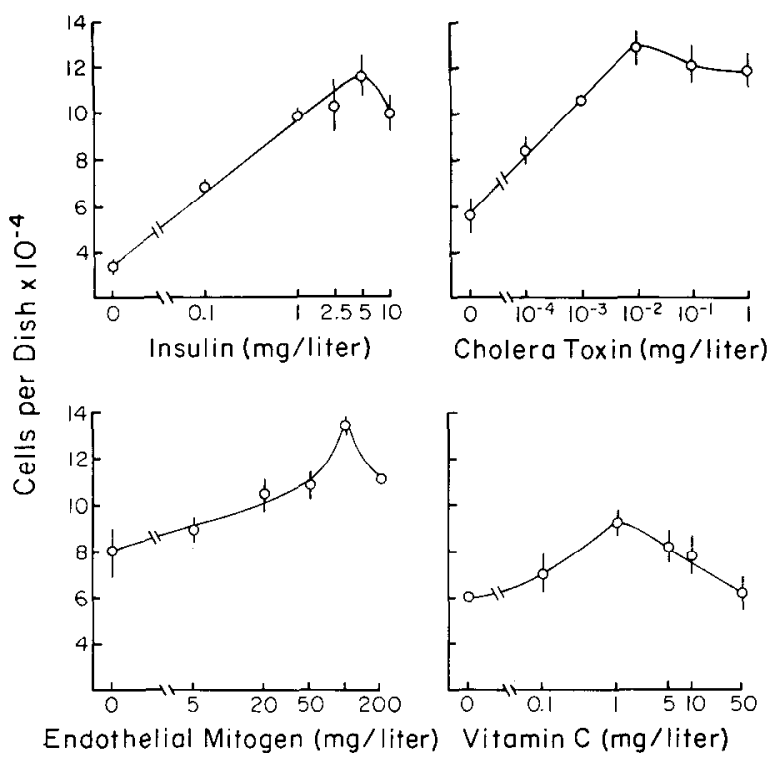

Figure 2. Growth response of primary cells in serum-free medium as a function of supplement concentration. Primary Schwann cell cultures were plated on $35 \mathrm{~mm}$ dishes coated with extracellular matrix and then pretreated with an antimitotic agent in the presence of $10 \%$ FBS (Procedure 1, Materials and Methods). Cell number was determined $5 \mathrm{~d}$ after the medium was changed to serum-free $\$ 3$ medium (Table 1). In each experiment, the concentration of 1 supplement was varied over the range indicated and the other supplements were held constant.

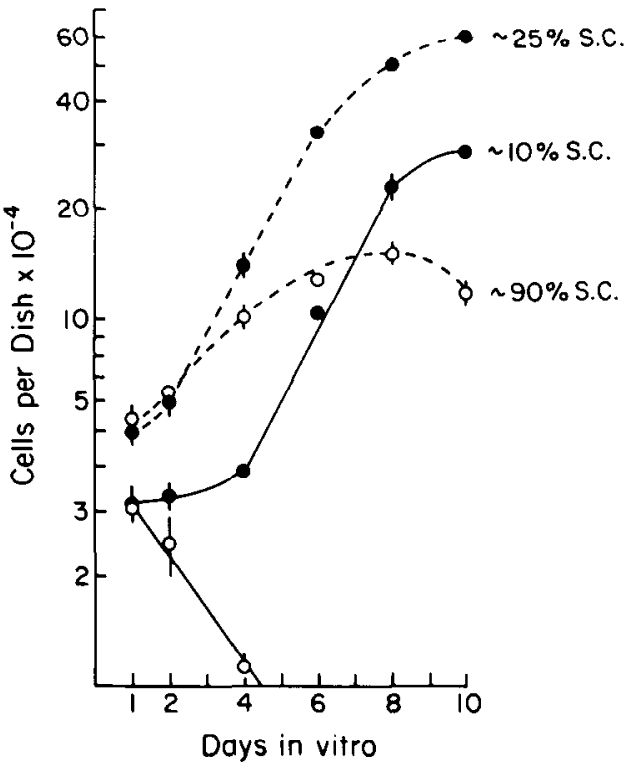

Figure 3. Growth of primary cells as a function of medium and substrate. Dissociated sciatic nerve cells were plated at densities of $1 \times 10^{5}$ cells $/ \mathrm{ml} / 35 \mathrm{~mm}$ dish in serum-free S4 medium (Table 1) (O), or S-MEM supplemented with $10 \%$ FBS and $0.01 \mathrm{mg} /$ liter cholera toxin (O) onto unmodified tissue culture plastic $(\longrightarrow)$ or ECM $(--)$. S.C., Ran-1positive Schwann cells (refer to Fig. 4).

cell number was determined for insulin, cholera toxin, endothelial mitogen, vitamin $\mathrm{C}$, transferrin, and putrescine. Optimal concentrations were found for insulin, cholera toxin, endothelial mitogen, and vitamin C (Fig. 2). Doses of transferrin up to 25 $\mathrm{mg} /$ liter had no effect on cell number, while doses above $25 \mathrm{mg}$ liter resulted in a decrease in cell number. Although putrescine exhibited only a minor effect on cell number at a dose of $8 \mathrm{mg} /$ liter, it was maintained at this concentration since it is in accord with the concentration found to be optimal for other neural cells (Ahmed et al., 1983).

\section{Selection against fibroblast proliferation}

Having determined some of the supplements that were optimal for growth of Schwann cells, the effects of different basal media werc evaluated. Various basal media, optimally supplemented for Schwann cell proliferation, were monitored for their effects on the relative proliferation of fibroblasts and Schwann cells as assessed by morphological criteria in primary cultures plated directly into serum-free medium on a substrate of ECM. After $8 \mathrm{~d}$ in serum-free medium, the percentage of cells exhibiting the Schwann cell morphology (small, phase-dark, and bipolar) was determined. This value was then used to obtain the absolute number of Schwann cells and fibroblasts per dish from the total cell number per dish. Neither a low-calcium medium nor MEM with $\mathrm{D}$-valine substituted for $\mathrm{L}$-valine, manipulations that have been successful for the selective growth of keratinocytes (Boyce and Ham, 1983) and epithelial cells (Gilbert and Migeon, 1975), respectively, from fibroblast-contaminated cultures, supported Schwann cell proliferation. D-Valine was toxic not only to fibroblasts, but also to Schwann cells. DMEM and Iscove's modification of DMEM (IMDM) both support fibroblast proliferation. Only MEM sustained Schwann cell growth at the same level as that sustained in DMEM and IMDM, while significantly inhibiting fibroblast proliferation. These data resulted in the 

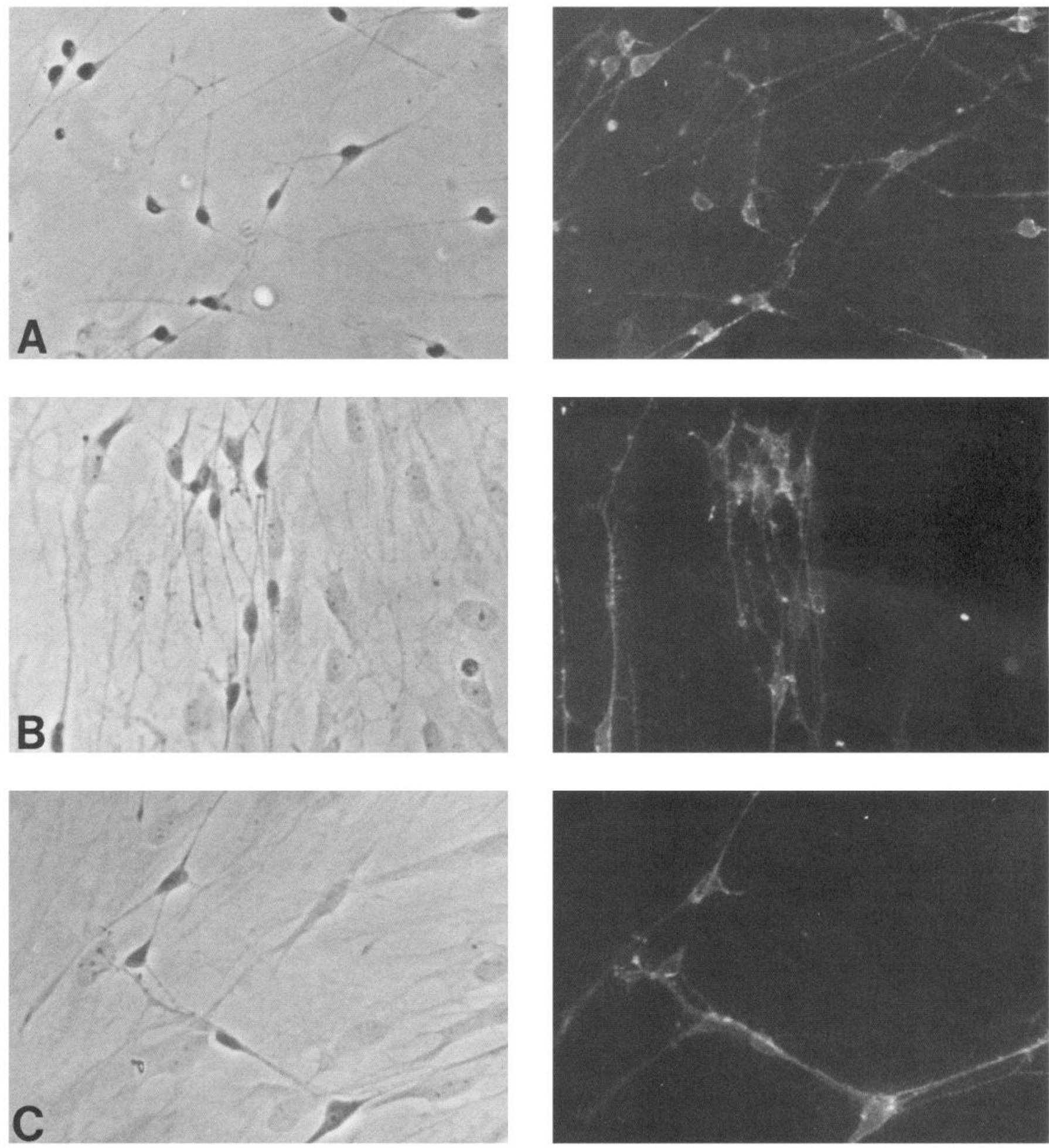

Figure 4. Indirect immunofluorescence of Ran-1-positive cells in primary cultures. Dissociated sciatic nerve cells were plated at densities of $1 \times$ $10^{5}$ cells $/ \mathrm{ml} / 35 \mathrm{~mm}$ dish as follows: $(A)$ on ECM in S4 serum-free medium (Table 1); $(B)$ on ECM in S-MEM supplemented with $10 \%$ FBS and $0.01 \mathrm{mg} /$ liter cholera toxin (S-MEM/10\% FBS/CTx); and $(C)$ on unmodified tissue culture plastic in S-MEM/10\% FBS/CTx. After $10 \mathrm{~d}$ in vitro, cultures were incubated with Ran-1 antiserum and labeled with fluorescein-conjugated goat anti-mouse immunoglobulins. The same field was visualized by phase contrast $(l e f t)$ and fluorescence microscopy $(r i g h t) . \times 640$.

formulation of S4 medium, which consists of the basal medium MEM supplemented with optimal concentrations of growthpromoting components (Table 1).

We next compared the rate of growth and the saturation den- sities of dissociated sciatic nerve cells established in S4 serumfree medium or in S-MEM supplemented with $10 \%$ FBS and $0.01 \mathrm{mg} /$ liter cholera toxin when plated either on ECM or unmodified tissue culture plastic (Fig. 3). Cells grown in the pres- 

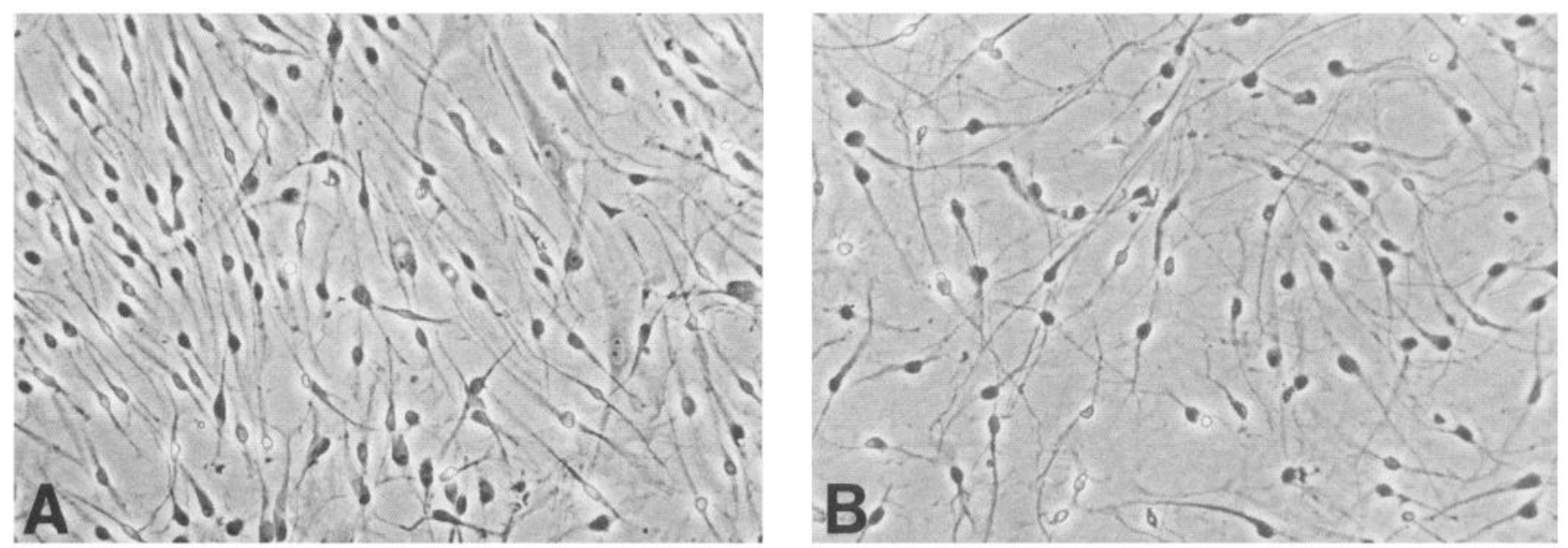

Figure 5. Phase-contrast photomicrographs of cultures established and maintained in S4 serum-free medium (Table 1) in ECM-coated flasks. A, Primary dissociated sciatic nerve culture after $7 \mathrm{~d}$ in vitro. $B$, Secondary culture (passage $4 ; 6$ weeks in vitro) purified upon first passage with antiThy 1.1 complement-mediated lysis. $\times 240$.

ence of fetal bovine serum exhibited a doubling time of $2 \mathrm{~d}$ on both ECM and plastic, and saturation densities of $6 \times 10^{5}$ and $2.5 \times 10^{5}$ cells/dish, respectively. Dissociated rat sciatic nerve cells plated on ECM in S4 exhibited a doubling time of $4 \mathrm{~d}$, with no lag in proliferation, and a saturation density of $1.3 \times$ $10^{5}$ cells/dish. In contrast, dissociated rat sciatic nerve cells plated on plastic in S4 showed only a decline in cell number after initial attachment. The use of ECM as a substrate, rather than tissue culture plastic, resulted in a $40 \%$ increase in seeding efficiency, irrespective of the medium used.

Indirect immunofluorescence analysis of these cultures after $10 \mathrm{~d}$ in vitro established that approximately $90 \%$ of the cells maintained on ECM in S4 were positive for the Ran-1 antigen, a Schwann cell marker (Brockes et al., 1977), as compared to $\sim 25$ and $\sim 10 \%$ Ran-1-positive cells in cultures maintained in serum on ECM and on plastic, respectively. All Ran-1-positive cells had the bipolar morphology characteristic of Schwann cells (Fig. 4). The remaining cells in the serum-free cultures were flat cells that were positive for Thy 1.1, a fibroblast marker (Brockes et al., 1977). However, at day 10, when the cultures maintained in the presence of serum were near confluence, many of the flat cells with a typical fibroblastic morphology were neither positive for the fibroblastic marker, Thy 1.1, nor for the Schwann cell marker Ran-1. Another fibroblast marker, antifibronectin, is not effective in this system because of the presence of fibronectin in the extracellular matrix. To characterize the cells further, they were examined for the expression of additional antigens by indirect immunofluorescence. These antigens included $217 \mathrm{c}$ (Fields and Dammerman, 1985) and S-100 (Brockes et al., 1979; Mirsky and Jessen, 1984), which are specific markers for Schwann cells in sciatic nerve cultures, and galactocerebroside, which is expressed exclusively by the Schwann cells in sciatic nerve cultures, although this expression is dependent on the phenotypic status of these cells both in vitro (Mirsky et al., 1980; Sobue and Pleasure, 1984)) and in vivo (Jessen et al., 1985). Further antigens examined were A5E3 and Ran-2, which are expressed by non-myelin-forming Schwann cells and by perineural cells in vivo (Jessen and Mirsky, 1984; Mirsky and Jessen, 1984; Mirsky et al., 1985). The expression of A5E3 and Ran-2 in vitro is also dependent on the phenotypic status of the cells (Jessen and
Mirsky, 1984). After $10 \mathrm{~d}$ in serum-free culture, the bipolar cells were positive for $217 \mathrm{c}, \mathrm{S}-100$, and A5E3, although they were negative for galactocerebroside and Ran-2. A small proportion of the flat cells in these cultures were positive for A5E3. In view of the congruence between the Schwann cell markers, it is likely that anti-Ran 1 labels all of the Schwann cells and that the remaining cells are fibroblastic. Furthermore, Morris and Beech (1984) have noted that fibroblasts in cultures of neonatal rat peripheral nervous tissue exhibit considerable variation in the intensity of labeling with anti-Thy 1.1 antiserum and that connective tissue elements of peripheral nerve lose Thy 1.1 expression in vivo as the rat matures.

\section{Serial subculture of Schwann cells in $S 4$ serum-free medium}

Secondary cultures of at least $99 \%$ purity may be established after anti-Thy 1.1 complement-mediated lysis of primary cultures maintained in S4 serum-free medium, as described in Materials and Methods. These secondary Schwann cells continue to proliferate in S4 when maintained on ECM, with no decrease in purity, through at least 4 passages and continue to maintain the bipolar morphology characteristic of primary Schwann cells (Fig. 5). Primary cultures of rat sciatic nerve maintained past confluence on ECM in S4 serum-free medium show a gradual increase in fibroblast contamination.

Maintenance of Schwann cells on ECM-coated flasks rather than dishes enhances Schwann cell viability in S4 serum-free medium. Primary cultures of Schwann cells in S4 reach a saturation density of $\sim 2.8 \times 10^{4}$ cells $/ \mathrm{cm}^{2}$ when maintained in 75 $\mathrm{cm}^{2}$ flasks containing $10 \mathrm{ml}$ of medium, as opposed to $1.6 \times$ $10^{4}$ cells $/ \mathrm{cm}^{2}$ when maintained in $35 \mathrm{~mm}$ dishes containing 1 $\mathrm{ml}$ of medium. This increase in cell density is not due to an increase in fibroblasts, as the level of fibroblast contamination is approximately $10 \%$ upon confluence under both regimens. In addition, purified Schwann cells show no apparent decrease in viability in serum-free S4 medium when maintained in ECMcoated flasks for as long as 4 weeks without passage; however, when Schwann cells were maintained in a $35 \mathrm{~mm}$ dish there was a decrease in viability (Fig. 3).

The optimal growth of Schwann cells in flasks, rather than in dishes, may be due to the relatively closed environment of the 
flasks, which may serve to buffer fluctuations in the ambient $\mathrm{CO}_{2}$, and hence the $\mathrm{pH}$ of the medium, or to decrease evaporation of water and subsequent shifts in osmolarity. Since medium is changed every $2 \mathrm{~d}$, and the incubator is humidified, the increased $\mathrm{pH}$ stability may be the mechanism of advantage.

\section{Discussion}

The culture of cells from neonatal dissociated rat sciatic nerve on ECM in S4 serum-free medium allows for the selective growth of Schwann cells to $90 \%$ purity after $10 \mathrm{~d}$ in vitro. The selection for Schwann cell proliferation and against fibroblast proliferation is mediated by supplementing a less enriched basal medium with components optimized for the support of Schwann cells. The finding that the use of the less enriched basal medium, MEM, rather than the more complex DMEM, as a base for serum-free medium results in the suppression of fibroblast proliferation while supporting Schwann cell proliferation is in agreement with observations of Krieder et al. (1981, 1982), who reported the same results using calf serum-supplemented media. Selection against fibroblasts may also be facilitated by the absence of exposure of the cells to the mesenchymal mitogens present in serum. Other components of the serum-free medium that may exert an influence on fibroblast proliferation are vitamin $C$, cholera toxin, and the endothelial mitogen. Vitamin $\mathrm{C}$ is toxic to chick, human, and mouse fibroblasts at concentrations of $10-50 \mathrm{mg} /$ liter, and fibroblasts at low densities are especially susceptible to these toxic effects (Peterkofsky and Prather, 1976). Cholera toxin, at concentrations as low as 1.68 ng/liter, inhibits DNA synthesis in human fibroblasts (Hollenberg and Cuatrecasas, 1973). Endothelial mitogen, a commercially available pituitary extract prepared by the method of Maciag et al. (1979), on the other hand, is a source of fibroblast growth factor (FGF) and has been shown to contain mitogenic activity for mouse 3T3 fibroblasts over the range of $15-150 \mathrm{mg}$ liter (Maciag et al., 1982).

Little is known about how factors that affect Schwann cell proliferation exert their influence. Although insulin is not a Schwann cell mitogen in serum-supplemented (Salzer and Bunge, 1980) or in N2 medium (Moya et al., 1980), it appears to be a stringent requirement for Schwann cell proliferation in response to mitogens in serum-free medium. In addition to cholera toxin and pituitary extract, which are well-established Schwann cell mitogens (Raff et al., 1978b), vitamin C enhances Schwann cell growth in serum-free medium. Vitamin $\mathrm{C}$ is also a required supplement to $\mathrm{N} 2$ for the expression of a basal lamina and the elaboration of myelin by Schwann cells cocultured with neurons (Bunge and Bunge, 1983). It is not known whether vitamin C influences proliferation and differentiation by a common mechanism. Although vitamin $\mathrm{C}$ is well known to promote elaboration of mature collagen (Peterkofsky, 1972), it has also been shown to stimulate the synthesis of noncollagen proteins in smooth muscle cells maintained in serum-free medium and to stimulate the growth of these cells even in the presence of agents that interfere with the formation of mature collagen (Libby and O'Brien, 1983). Compounds that increase the cellular levels of cAMP have also been shown to exert dual effects on Schwann cells. Dibutyryl cAMP and 8-bromo cAMP are mitogenic for Schwann cells at concentrations of 1 to $5 \times 10^{-4} \mathrm{M}$; however, at higher concentrations $\left(1 \times 10^{-3} \mathrm{M}\right)$ these compounds inhibit proliferation and enhance the expression of galactocerebroside (Sobue and Pleasure, 1984). Although cholera toxin's mitogenic effects appear to be mediated by an increase in cellular cAMP (Raff et al., 1978a), cholera toxin has not been demonstrated to influence Schwann cell differentiation.

The remaining supplements are essentially those of the serumfree medium developed by Ahmed et al. (1983) for the longterm culture of dissociated cells from the rat $\mathrm{CNS}$, with the deletion of additional $\mathrm{KCl}$ and of transferrin. Although transferrin is usually required for cell culture in serum-free medium, purified astrocytes also exhibit no requirement for transferrin (Morrison and de Vellis, 1981).

Several serum-free medium formulations have been reported to support the proliferation of Schwann or Schwannoma cells in culture. Rat Schwann cells multiply in Bottenstein and Sato's N2 medium only in the presence of neurons (Moya et al., 1980). Other work (Cassel et al., 1982), as well as our own, indicates that Schwann cells are also capable of proliferating in N2 in response to soluble mitogens (cholera toxin, dibutyryl cAMP, and pituitary extract). However, there has been no report of serial propagation of pure Schwann cells in serum-free medium. Serial propagation of rat Schwannoma cells has been accomplished in Michler-Stuke and Bottenstein's G3 medium (1982). These authors reported that DMEM offered better support for Schwannoma cell proliferation in serum-free medium than either a 1:1 mixture of DMEM and F12 or F12 alone. We were able to extend this finding to the proliferation of normal purified Schwann cells in serum-free medium. However, in the course of studies preliminary to the work reported here, we found that G3 will not support the growth of normal purified Schwann cells even if supplemented with cholera toxin. G3 medium lacks insulin, which may explain the failure of Schwann cells to proliferate in this medium. G3 medium also lacks fatty acids in complex with albumin, and the additional amino acids and vitamins that we have found to increase the viability of normal Schwann cells. This finding agrees with that of $\Lambda$ hmed et al. (1983), who reported that these supplements increased the viability of normal CNS neurons. Thus, the ability of S4 medium to support the serial propagation of Schwann cells may be due to the fulfillment of basal metabolic and mitogenic requirements for Schwann cell proliferation.

$\mathrm{S} 4$ is not a "defined" medium. The major undefined elements in this system are the ECM substrate, the fatty acid-free BSA, and the pituitary extract, endothelial mitogen, prepared by ICN Biochemicals by the method of Maciag et al. (1979). This extract is a source of FGF (Esch et al., 1985). Furthermore, SDS-PAGE analysis of endothelial cell mitogen demonstrated the presence of many bands, including one in the region of $30 \mathrm{kDa}$ (unpublished observations), which corresponds to the molecular weight of the glial growth factor of pituitary described by Brockes et al. (1980b) and Lemke and Brockes (1984). While glial growth factor is mitogenic for Schwann cells in serum-containing medium, FGF, epidermal growth factor, and NGF are not, nor are a series of anterior and posterior pituitary hormones (Raff et al., 1978a). Further experiments are planned to determine whether purified glial growth factor and/or endothelial cell growth factor can replace endothelial mitogen in serum-free medium.

Many Schwann cell antigens and their expression in association with developmental changes have been described. Some of these antigens, such as Ran-1, S-100 (Brockes et al., 1979; Mirsky and Jessen, 1984), and 217c (Fields and Dammerman, 1985), appear to be constitutively expressed. The myelin proteins $\mathrm{P}_{0}, \mathrm{P}_{1}$ (myelin basic protein), and $\mathrm{P}_{2}$ are expressed solely 
by myelin-forming cells in vivo (Trapp et al., 1979; Brockes et al., 1980a, b), while non-myelin-forming Schwann cells express Ran-2, A5E3, and glial fibrillary acidic protein in vivo (Jessen and Mirsky, 1984). Recent evidence suggests that the expression of the glycosphingolipid galactocerebroside may correlate not with myelin formation, but rather with the cessation of cell division in vivo (Jessen et al., 1985). Previous studies have demonstrated that after short periods of culture in serum-containing medium, Schwann cells isolated from neurons fail to express immunohistochemically identifiable galactocerebroside, the myelin proteins, and Ran-2, although they express Ran-1, S-100, 217c, and A5E3 (Brockes et al., 1979; Mirsky et al., 1980; Jessen and Mirsky, 1984; Mirsky and Jessen, 1984; Fields and Dammerman, 1985). Thus, these isolated Schwann cells fail to coexpress the constellation of antigens characteristic not only of myelin-forming but also of non-myelin-forming axon-associated Schwann cells in the mature rat. Furthermore, these Schwann cells are also devoid of a basal lamina and have been shown to resynthesize a basal lamina only in coculture with neurons (Bunge et al., 1982). In fact, studies by the Bunges' group have suggested that the formation of a basal lamina by the Schwann cell is a prerequisite in the process of Schwann cell differentiation and is necessary for subsequent axonal ensheathment and myelination by Schwann cells (Bunge and Bunge, 1983). Since Schwann cell differentiation may be dependent upon the formation of a basal lamina, we have supplied isolated Schwann cells grown in serum-free medium with an exogenous basal lamina-like scaffold in the form of the ECM of bovine aorta endothelial cells. We report, however, that cells grown in these conditions also fail to coexpress the constellation of antigens characteristic of mature myelin-forming Schwann cells in situ. While an ECM from endothelial cells is sufficient to maintain the differentiated phenotype of chondrocytes in culture (Kato and Gospodarowicz, 1985), it is possible that biomatrices prepared from sciatic nerve (Johnson et al., 1982; Reid and Jefferson, 1984) may be more effective.

The ability to grow Schwann cells in a serum-free medium on ECM is a step towards defining the requirements for Schwann cell growth and the maintenance of the differentiated phenotype. Further studies will be directed toward determining how alterations in particular components of the medium affect the expression of differentiation markers. These studies should be aided by a culture system that does not rely upon the use of antimitotic agents to control fibroblast proliferation. Antimitotic agents have deleterious effects even on postmitotic cells, as indicated by the dose-dependent inhibition of neurite extension in cultures of autonomic neurons. Although the deleterious effects of these agents are reversible upon withdrawal of the antimitotic agent (Argiro and Johnson, 1981), alternative methods should allow the unambiguous characterization of cellular properties throughout the lifetime of the culture.

\section{References}

Aguayo, A., L. Charron, and G. Bray (1976) Potential of Schwann cells from unmyelinated nerves to produce myelin: A quantitative ultrastructural and radiographic study. J. Neurocytol. 5: 565-573.

Ahmed, 7.. P. S. Walker, and R. E. Fellows (1983) Properties of neurons from dissociated fetal rat brain in serum-free culture. J. Neurosci. 3: $2448-2462$.

Argiro, V., and M. Johnson (1981) Inhibition of neurite extension by fluorodeoxyuridine is age dependent, dose dependent and reversible. Soc. Neurosci. Abstr. 7: 346.

Bartlett, P. F., M. D. Noble, R. M. Pruss, M. C. Raff, S. Rattray, and
C. A. Williams (1981) Rat neural antigen-2 (Ran-2): A cell surface antigen on astrocytes, ependymal cells, Müller cells and lepto-meninges defined by a monoclonal antibody. Brain Res. 204: 339-351.

Bottenstein, J. E., and G. H. Sato (1979) Growth of a rat neuroblastoma cell line in serum-free supplemented medium. Proc. Natl. Acad. Sci. USA 76: 514-517.

Boyce, S. T., and R. G. Ham (1983) Calcium-regulated differentiation of normal human epidermal keratinocytes in chemically defined clonal culture and serum-free serial culture. J. Invest. Dermatol. $81: 33 \mathrm{~s}-$ $40 \mathrm{~s}$.

Brockes, J. P., K. L. Fields, and M. C. Raff (1977) A surface antigenic marker for rat Schwann cells. Nature 266: 364-366.

Brockes, J. P., K. L. Fields, and M. C. Raff (1979) Studies on cultured rat Schwann cells. I. Establishment of purified populations from cultures of peripheral nerve. Brain Res. 165: 105-118.

Brockes, J. P., M. C. Raff, D. J. Nishiguchi, and J. Winter (1980a) Studies on cultured rat Schwann cells. III. Assays for peripheral myelin proteins. J. Neurocytol. 9: 67-77.

Brockes, J. P., G. E. Lemke, and D. R. Balzer (1980b) Purification and preliminary characterization of a glial growth factor. J. Biol. Chem. 255: 8374-8377.

Bunge, M. B., A. K. Williams, and P. M. Wood (1982) NeuronSchwann cell interaction in basal lamina formation. Dev. Biol. 92 . 449-460.

Bunge, R. P., and M. B. Bunge (1983) Interrelationship between Schwann cell function and extracellular matrix production. Trends Neurosci. 6: 499-505.

Cassel, D., P. M. Wood, R. P. Bunge, and L. Glaser (1982) Mitogenicity of brain axolemma membranes and soluble factors for dorsal root ganglion Schwann cells. J. Cell Biochem. 18: 433-445.

Esch, F., A. Baird, N. Ling, N. Ueno, F. Hill, L. Denoroy, R. Klepper, D. Gospodarowicz, P. Bohlen, and R. Guillemin (1985) Primary structure of bovine pituitary basic fibroblast growth factor (FGF) and comparison with the amino terminal sequence of bovine brain acidic FGF. Proc. Natl. Acad. Sci. USA 82: 6963-6967.

Fields, K. L., and M. Dammerman (1985) A monoclonal antibody equivalent to anti-rat neural antigen-1 as a marker for Schwann cells. Neuroscience 15: 877-885.

Gilbert, S. F., and B. R. Migeon (1975) D-Valine as a selective agent for normal human and rodent epithelial cells in culture. Cell 5 : 1117.

Gospodarowicz, D., G. Greenburg, J. M. Foidart, and N. Savion (1981) The production and localization of laminin in cultured vascular and corneal endothelial cells. J. Cell. Phys. 107: 171-183.

Hollenberg, M. D., and P. Cuatrecasas (1973) Epidermal growth factor: Receptors in human fibroblasts and modulation of action by cholera loxin. Proc. Natl. Acad. Sci. USA 70: 2964-2968.

Jessen, K. R., and R. Mirsky (1984) Nonmyelin-forming Schwann cells coexpress surface proteins and intermediate filaments not found in myelin-forming cells: A study of Ran-2, A5E3 antigen and glial fibrillary acidic protein. J. Neurocytol. 13: 923-934.

Jessen, K. R., L. Morgan, M. Brammer, and R. Mirsky (1985) Galactocerebroside is expressed by non-myelin-forming Schwann cells in situ. J. Cell Biol. 101: 1135-1143.

Johnson, P. C., R. C. Duchamel, E. Meezan, and K. Brendel (1982) Preparation of cell-free extracellular matrix from human peripheral nerve. Muscle Nerve 5: 335-344.

Kato, Y., and D. Gospodarowicz (1985) Effect of exogenous extracellular matrices on proteoglycan synthesis by cultured rabbit costal chondrocytes. J. Cell Biol. 100: 486-495.

Kramer, R. H., R. Gonzalez, and G. L. Nicolson (1980) Metastatic tumor cells adhere preferentially to the extracellular matrix underlying vascular endothelial cells. Int. J. Cancer 26: 639-645.

Kreider, B. Q., A. Messing, H. Doan, S. O. Kim, R. P. Lisak, and D. E. Pleasure (1981) Enrichment of Schwann cell cultures from neonatal rat sciatic nerve by differential adhesion. Brain Res. 207: 433444.

Kreider, B. Q., J. Corey-Bloom, R. P. Lisak, H. Doan, and D. E. Pleasure (1982) Stimulation of mitosis of cultured rat Schwann cells isolated by differential adhesion. Brain Res. 237: 238-243.

Lemke, G. E., and J. P. Brockes (1984) Identification and purification of glial growth factor. J. Neurosci. 4: 75-83.

Libby, P., and K. V. O'Brien (1983) Culture of quiescent arterial smooth muscle cells in a defined serum-free medium. J. Cell. Physiol. 115: 217-223. 
Maciag, T., J. Cerundolo, S. Ilsley, P. R. Kelly, and R. Forand (1979) An endothclial ccll growth factor from bovine hypothalamus: Identification and partial characterization. Proc. Natl. Acad. Sci. USA 76: 5674-5678.

Maciag, T., G. A. Hoover, and R. Weinstein (1982) High and low molecular weight forms of endothelial cell growth factor. J. Biol. Chem. 257: 5333-5336.

Michler-Stuke, A., and J. E. Bottenstein (1982) Defined media for the growth of human and rat glial derived cells. In Growth of Cells in Hormonally Defined Media, G. H. Sato, A. B. Pardee, and D. A. Sirbasku, eds., pp. 959-971, Cold Spring Harbor Laboratory, New York.

Mirsky, R., and K. R. Jessen (1984) A cell surface protein of astrocytes, Ran-2, distinguishes non-myelin-forming Schwann cells from myelinforming Schwann cells. Dev. Neurosci. 6: 304-316.

Mirsky, R., J. Winter, E. R. Abncy, R. M. Pruss, J. Gavrilovic, and M. C. Raff (1980) Myelin-specific proteins and glycolipids in rat Schwann cells and oligodendrocytes in culture. J. Cell Biol. 84: 483-494.

Mirsky, R., J. Gavrilovic, P. Bannerman, J. Winter, and K. R. Jessen (1985) Characterization of a plasma membrane protein shared by non-myelin forming PNS and CNS glia, a subpopulation of PNS neurons, perineural cells and smooth muscle. Cell Tissue Res. 240: 723-733.

Morris, R. J., and J. N. Beech (1984) Differential expression of Thy-1 on the various components of connective tissue of rat nerve during postnatal development. Dev. Biol. 102: 32-42.

Morrison, R. S., and J. de Vellis (1981) Growth of purified astrocytes in chemically defined medium. Proc. Natl. Acad. Sci. USA 78: 7205 7209.

Moya, F., M. B. Bunge, and R. P. Bunge (1980) Schwann cells proliferate but fail to differentiate in defined medium. Proc. Natl. Acad. Sci. USA 77: 6902-6906.

Needham, L., G. McKhann, and G. Tennekoon (1985) Schwann cells: Selective growth in neuron- and serum-free primary cultures. Trans. Am. Soc. Neurochem. 16: 239.

Peng, W. W., J. P. Bressler, E. Tiffany-Castiglioni, and J. de Vellis (1982) Development of a monoclonal antibody against a tumor-associated antigen. Science 215: 1102-1104.

Peterkofsky, B. (1972) The effect of ascorbic acid on collagen poly- peptide synthesis and proline hydroxylation during the growth of cultured fibroblasts. Arch. Biochem. Biophys. 152: 318-328.

Peterkofsky, B., and W. Prather (1976) Cytotoxicity of ascorbate and other reducing agents towards cultured fibroblasts as a result of hydrogen peroxide formation. J. Cell. Physiol. 90: 61-70.

Raff, M. C., K. L. Fields, S. Hakomori, R. Mirsky, M. Pruss, and J. Winter (1979) Cell-type specific markers for distinguishing and studying neurons and the major classes of glial cells in culture. Brain Res. 174: 283-308.

Raff, M. C., A. Abney, J. P. Brockes, and A. Hornby-Smith (1978a) Schwann cell growth factors. Cell 15: 813-822.

Raff, M. C., A. Hornby-Smith, and J. P. Brockes (1978b) Cyclic AMP as a mitogenic signal for cultured rat Schwann cells. Nature 273:672673.

Ranscht, B., P. A. Clapshaw, J. Price, M. Noble, and W. Seifert (1982) Development of oligodendrocytes and Schwann cells studied with a monoclonal antibody against galactocerebroside. Proc. Natl. Acad. Sci. USA 79: 2709-2713.

Reid, L. M., and D. M. Jefferson (1984) Cell culture studies using extracts of extracellular matrix to study growth and differentiation in mammalian cells. In Mammalian Cell Culture: The Use of Serumfree Hormone-Supplemented Media, J. P. Mather, ed., pp. 239-280, Plenum, New York.

Salzer, J. L., and R. P. Bunge (1980) Studies of Schwann cell proliferation. I. An analysis in tissue culture of proliferation during development, Wallenian degeration and direct injury. J. Cell Biol. 84: 739752

Sobue, G., and D. Pleasure (1984) Schwann cell galactocerebroside induced by derivatives of adenosine $3^{\prime}, 5^{\prime}$-monophosphate. Science 224: 72-74.

Trapp, B. D., L. J. McIntyre, R. H. Quarles, N. H. Sternberger, and H. Webster (1979) Immunocytochemical localization of rat peripheral nervous system myelin proteins: $P_{2}$ protein is not a component of all peripheral nervous system myelin sheaths. Proc. Natl. Acad. Sci. USA 76: 3552-3556.

Vlodavsky, I., R. Ariav, R. Atzmon, and Z. Fuks (1982) Tumor cell attachment to the vascular endothelium and subsequent degradation of the subendothelial extracellular matrix. Exp. Cell Res. 140: 149159. 